脳転移巣摘出術後に原発癌病巣を切除した 5 例の検討

\begin{tabular}{|c|c|c|c|c|c|c|c|c|c|c|c|}
\hline & & & & 大椖 & 警察 & 㞫院 & 外科 & & & & \\
\hline 野 & 村 & 昌 & 哉 & 中 & 尾 & 量 & 保 & 仲 & 原 & 正 & 明 \\
\hline 荻 & 野 & 信 & 夫 & 藤 & 田 & 修 & 弘 & 前 & 田 & 克 & 昭 \\
\hline & 場 & 健 & 義 & 江 & 本 & & 節 & 黑 & 住 & 和 & 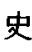 \\
\hline & & & & 同 & & & & & & & \\
\hline & & & & 岩 & 永 & 秀 & 昭 & & & & \\
\hline
\end{tabular}

脳転移巣摘出術後に原発癌病巣を切除した 5 症例の臨床的検討を行った. 原発巣は肺 3 例, 食道 1 例, 乳腺 1 例て, 全例脳転移による症状が先行した. 脳転移は単発性 4 例, 多発性 1 例で, 脳転移巣摘出から原発巣切除までの期間は $0.5 \sim 6$ 力であった. 全例が 原発巣切除より 1 年以上生存した. 脳転移巣摘出術後に全脳照射を施行しなかった肺癌 の 2 例は脳転移再発で原発巣切除後 1 年 2 力月， 1 年 3 力月で死亡した．全脳照射を施 行した 3 例は脳転移再発を認めず, 肺癌の無再発生存 1 例 ( 3 年 1 力月), 食道癌の再発 生存 1 例 ( 2 年 6 力月), 乳癌の再発死亡 1 例 ( 1 年 2 力月) であった. 2 年以上生存の 2 例は原発巣, 脳転移巣ともに治瘾切除がなされていた。

進行度に応じた転移性脳腫瘍に対する脳転移巣摘出，原発巣切除および術後全脳照射 は，予後の改善に有用と考えられた。

索引用語：転移性脳腫㿟

\section{緒言}

近年, 癌治療の進歩にともない癌患者の生存期間が 延長し, 転移性脳腫湯の発生頻度も增加しつつある。 転移性脳腫揚は根治を期待しがたいことが多いが，積 極的な外科治療を含む集学的治療により長期生存する 症例もあり，その治療に関して未だ一定の見解が得ら れていない，今回われわれは，脳転移による症状が先 行した進行癌 5 例に対し，原発癌病巣切除に先立ち脳 転移巣摘出術を施行し比較的良好な結果を得たので報 告する.

\section{症例の内訳}

対象は1990年 5 月から1994年 3 月までに，脳転移巣 摘出術後に原発癌病巣を切除した 5 例である. 年齢は 39〜69歳, 平均55歳で, 男性 1 例, 女性 4 例であった (表 1 )。原発蔵器は肺が 3 例, 食道, 乳腺が各 1 例で あった。全例に脳転移による症状が先行し，perfor mance status は 1 例（症例 1 ）で 2 ，他の 4 例で 3 に 低下していた。
脳転移部位はテント上が 4 例，テント下が 1 例で， 転移個数は単発 4 例, 多発 1 例であった。 2 例（症例 2,4）において脳転移巣に対し複数回の手術を要し たが, 全例で肉眼的に全摘出された。術後全脳照射 $(40$ Gy）を 3 例に施行した。

初回脳転移巣手術から原発巣手術までの期間は 2 週 間から 6 力月であった。 6 力月を要した 2 例(症例 2 , 4) は転移巣に複数回の手術を要しその後原発巣が判 明した症例であった。

原発宩に対する術式は肺葉切除 3 例, 食道亜全摘 1 例, 定型的乳房切断 1 例で, 2 年以上の生存を得た 2 例（症例 3，4）で治癒切除が可能だったのに対し， 他の 3 例は非治癒切除であった。

予後については, 全例が原発巣切除より 1 年以上生 存した。術後全脳照射を施行せず原発巣が相対非治㦄 切除であった肺癌 2例（症例 1，2）は脳転移再発で 死亡したが，他の 3 例は脳転移巣の再発を認めなかっ た.

症例

症例 $1: 65$ 歳, 女性. 
表 1 脳転移巣摘出術後に原発癌病巣を切除した 5 症例

\begin{tabular}{|c|c|c|c|c|c|c|c|c|}
\hline No & 年齢/性 & $\begin{array}{c}\text { 原発巣 } \\
\text { (組織型) }\end{array}$ & $\begin{array}{l}\text { 脳転移 } \\
\text { 個数 }\end{array}$ & $\begin{array}{l}\text { 術後全 } \\
\text { 脳照射 }\end{array}$ & $\begin{array}{l}\text { 原発巣手 } \\
\text { 術までの) } \\
\text { 期間(月) }\end{array}$ & $\begin{array}{c}\text { 原発巣手術 } \\
\text { (原発巣進行度) }\end{array}$ & 再発部位 & $\begin{array}{c}\text { 予後 } \\
\text { (原発䉓切除 } \\
\text { からの期間) }\end{array}$ \\
\hline 1 & $65 / F$ & $\begin{array}{c}\text { 肺 } \\
\text { (高分化腺癌) }\end{array}$ & 巣発 & $(-)$ & 1 & $\begin{array}{l}\text { 右上葉切除 } \\
\text { (pT2N2M1) }\end{array}$ & 脳 & $\begin{array}{c}\text { 死亡 } \\
\text { ( } 1 \text { 年 } 2 \text { 力月) }\end{array}$ \\
\hline 2 & $49 / \mathrm{F}$ & $\begin{array}{c}\text { 肺 } \\
\text { (高分化腺癌) }\end{array}$ & 多発* & $(-)$ & 6 & $\begin{array}{c}\text { 左下葉切除 } \\
\text { (pT2N2M1) }\end{array}$ & 肺門リンンパ節 & $\begin{array}{c}\text { ( } 1 \text { 死亡 } \\
\text { 年 } 3 \text { 力 })\end{array}$ \\
\hline 3 & $39 / \mathrm{M}$ & (大細胞癌) & 巣発 & $(+)$ & 0.5 & $\begin{array}{l}\text { 右上葉切除 } \\
\text { (pT2N0M1) }\end{array}$ & $(-)$ & ( 3 年1 1 存 \\
\hline 4 & $55 / F$ & (類基底道細胞癌) & 巣発* & $(+)$ & 6 & $\begin{array}{l}\text { 食道要全摘 } \\
\text { 管䅡部吻合 } \\
\left(\mathrm{a}_{2} \mathrm{n}_{1} \mathrm{~m}_{1} \mathrm{pl}_{0}\right)\end{array}$ & 肝, 骨 & ( 2 年 6 生存 \\
\hline 5 & $69 / \mathrm{F}$ & $\begin{array}{c}\text { 乳腺 } \\
\text { (浸潤性乳癌) }\end{array}$ & 栄発 & $(+)$ & 1 & $\begin{array}{c}\text { 定型的乳房切断 } \\
\text { 復直筋皮弁再建 } \\
\left(\mathrm{t}_{4} \mathrm{n}_{3} \mathrm{~m}_{1}\right)\end{array}$ & $\begin{array}{c}\text { 肝, 骨, } \\
\text { 皮萠 }\end{array}$ & $\begin{array}{c}\text { ( } 1 \text { 死亡 } \\
\text { 年 } 2 \text { 月 })\end{array}$ \\
\hline
\end{tabular}

*原発栄手術に先立ち 2 回の脳転移巣摘出術を施行

1991年 1 月より記銘力障害が出現. 頭部 CT 検査で 右後頭葉に径 $3.5 \mathrm{~cm}$ 大の腫瘤像を認めた。また胸部 X 線, 胸部 CT 検査で右肺上葉に腫瘤像を認めた. 肺癌 脳転移と診断し，3月18日に脳転移巣摘出術，4月16 日に右肺上葉切除術を施行した。病理診断は高分化腺 癌で, pT2N2M1であった. 術後経口抗癌昘にて経過観 察していた。原発巣切除後 1 年 2 力月目に脳転移再発 で死亡した。

症例 $2: 49$ 歳, 女性.

1990年 4 月より右上下肢不全麻痺, 嘔吐, 頭痛が出 現. 頭部 CT 検査で左右頭頂葉および右側頭葉に計 3 個の腫瘤像を認めた。原発不明の多発性転移性脳腫場 と診断し，5月18日および 6 月 7 日に 2 回の脳転移巣 摘出術を施行し, 病理診断は中分化腺癌であった。 7 月の胸部 CT 検查で左肺下葉に径 $2 \mathrm{~cm}$ 大の腫瘤像を 認め, その後増大傾向を認め，肺が原発巣と判断し11 月 6 日左肺下葉切除術を施行した. 病理診断は高分化 腺癌で, pT2N2M1であった。全身静注化学療法を 2 クール施行後退院. 1991年 7 月より嘔吐が出現し, 頭 部 CT 検査で脳転移巣再発を認め，8月15日および 8 月29日に 2 回の摘出術を施行した。原発巣切除術 1 年 3 力月目に脳転移再発で死亡した。

症例 $3: 39$ 歳, 男性.

1993年 1 月より右上下肢不全麻痺が出現. 頭部 CT 検査で左頭頂葉に径 $4 \mathrm{~cm}$ 大の腫瘤像を認めた。また胸 部 CT 検査で右肺上葉に径 $3 \mathrm{~cm}$ 大の腫瘤像を認めた (図 1 ). 肺癌脳転移と診断し，3月 8 日に脳転移巣摘 出術，3月25日に右肺上葉切除術を施行した，病理診 断は大細胞癌で, pT2N0M1であった。術後全脳照射40 Gy を施行した. 原発巣切除後 3 年 1 力月目の現在再 発を認めず生存中である。

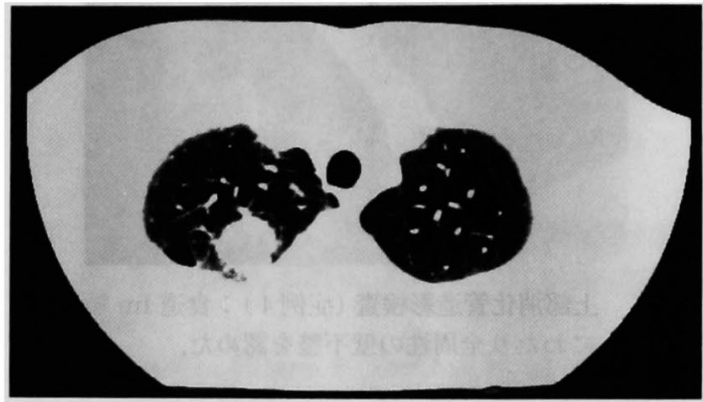

図 1 胸部 CT 検查 (症例 3 )：右肺上葉に径 $3 \mathrm{~cm}$ 大の 辺縁不整の腫瘤像を認めた。

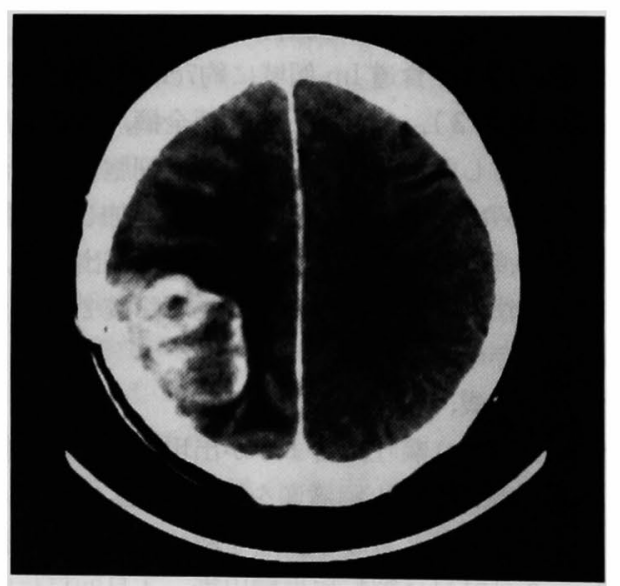

図 2 頭部 CT 検査 (症例 4)：脳転移巣摘出術後に左 頭頂葉に径 $4.5 \mathrm{~cm}$ 大の再発巣を認めた.

症例 $4: 55$ 歳, 女性.

1993年 4 月より意識障害が出現. 頭部 CT 検査で左 頭頂葉に径 $5.5 \mathrm{~cm}$ 大の腫瘤像を認め, 某院にて 5 月 1 日脳腫瘍摘出術を施行. 術後組織にて転移性脳腫瘍 (低 


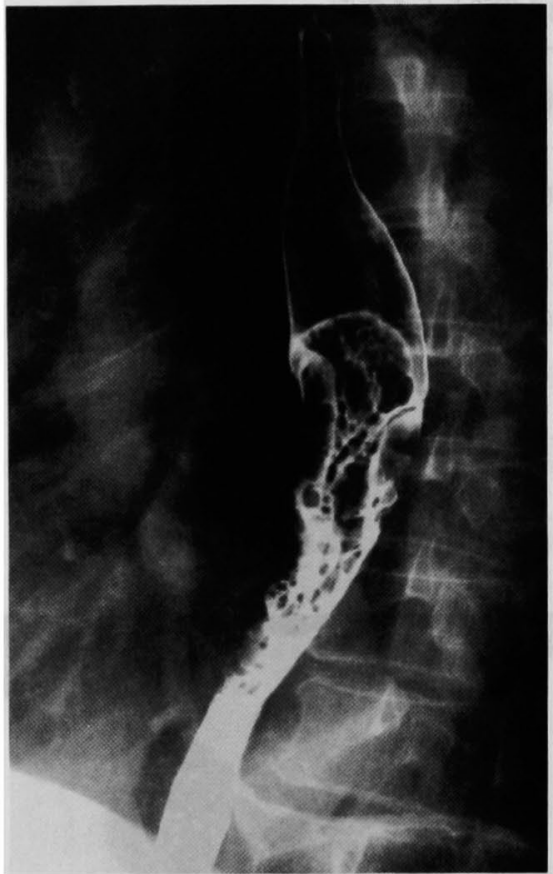

図 3 上部消化管造影検査 (症例 4) : 食道 Im 領域に $7 \mathrm{~cm}$ にわたり全周性の壁不整を認めた。

分化腺癌）が疑われた. 8 月の頭部 CT 検査で左頭頂 葉に径 $4.5 \mathrm{~cm}$ 大の再発巣を認め(図 2 ), 当院脳外科に て 9 月24日 2 回目の脳転移巣摘出術を施行した。10月 4 日より全脳照射 $20 \mathrm{~Gy}$ を施行したが，同時期の上部 消化管造影検査で食道 $\mathrm{Im}$ 領域に約 $7 \mathrm{~cm}$ にわたり壁不 整を認めた（図 3 )。10月26日食道要全摘，胃管頸部食 道吻合を施行した。病理診断は類基底細胞癌で, $\mathrm{a}_{2} \mathrm{n}_{1}$ $\mathrm{m}_{1} \mathrm{pl}_{0}$ であった，術後全脳照射 $20 \mathrm{~Gy}$ を追加した．原発 巣切除 1 年後に肝転移, 2 年後に骨転移が出現し, 肝 動注化学療法などを施行し, 原発巣切除後 2 年 6 力月 目の現在生存中である.

症例 5 : 69歳, 女性.

1994年 2 月より嘔吐, 目まいが出現. 頭部 CT 検査 で右小脳に径 $3 \mathrm{~cm}$ 大の腫瘤像を認めた(図 4 )。また左 乳腺に皮虞浸潤をともなう腫瘤を認め, 乳癌脳転移と 診断し，3 月31日に脳転移巣摘出術，4 月28日に定型 的乳房切断術および腹直筋皮弁による植皮を施行し た。病理診断は浸潤性乳管癌で, $\mathrm{t}_{4} \mathrm{n}_{3} \mathrm{~m}_{1}$ であった。術 後全脳照射 $40 \mathrm{~Gy}$ を施行し, 肝, 骨および皮成転移に対 し肝動注化学療法を 1 回, 全身静注化学療法を 7 クー ル，局所放射線療法を施行した. 原発巣切除後 1 年 2 力月目に癌死したが，経過中に明らかな脳転移巣再発

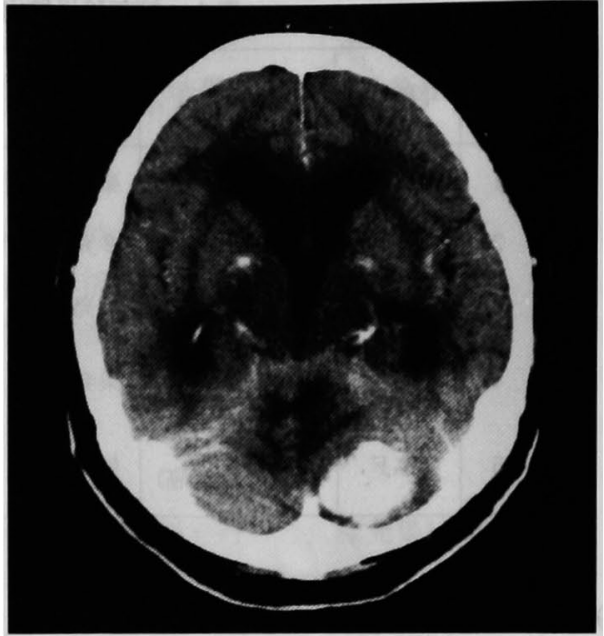

図4 頭部 CT 検査 (症例 5 )：右小脳に径 $3 \mathrm{~cm}$ 大の腫 瘤像を認めた。

を認めなかった。

\section{考察}

転移性脳腫瘍の中でも，原発巣が不明または脳転移 による症状が先行する症例（以下，脳先行型と略記） はしばしば経験され, 治療法の選択に苦慮することが 多い。小林ら”は転移性脳腫瘍85例中脳先行型が36例 （42\%）を占めたと報告している．また脳先行型の原発 巣で最も多いのは肺で, 特に腺癌が多いとされてい $3^{21}$. 自験例 5 例中 3 例は原発巣が肺で, うち 2 例が腺 癌であった。

徳力ら ${ }^{31}$ は転移性脳腫瘍の手術適応として, (1)脳転 移巣による症状があること, (2)原則として単発性であ ること, (3)手術可能な部位に存在すること, (4)全身状 態が比較的良好であることの 4 つを挙げた．松谷ら は多発性では, 2 回までの開頭で肉眼的全摘出が可能 な症例は手術適応としている. 自験例では全例これら の適応を満たし, 多発性の症例 2 は 2 回の開頭で全摘 出可能と判断した。転移巣摘出時にすでに原発巣が発 見されていた 3 例（症例 $1 ， 3 ， 5$ ）では，脳転移に よる脳障害が生命予後に最もかかわる因子と考えられ たので脳転移巣摘出を先行した。これらの症例では術 後比較的早期に神経症状が改善し, 術後 1 力月以内に 原発巣手術を施行することができた。

転移性脳腫場に対し，摘出術が有用であるとする報 告は散見される ${ }^{4)}$. Patchell ら ${ }^{5}$ は単発性の転移性脳腫 瘍48例において, 手術および術後照射併用群25例と放 射線療法単独群23例を無作為に比較検討し，各々の局 
所再発率は $20 \%$ 対 $52 \%$, 無再発期間は59週以上対 21 週, 平均生存期間は40週対15週であり，術後照射を併用し た摘出手術は局所制御に優れ予後を改善したと述べて いる. 自験例ては全例で転移巣術後早期に perfor mance statusは0または 1 に改善した。

転移性脳腫瘍の多くは境界明膫で，手術で肉眼的に 全摘出可能な場合が多いが，術後照射による脳再発予 防は重要である2). 山下ら ${ }^{61}$ は53例の肺癌脳転移例を検 討し, 手術および術後照射併用群の平均生存期間は6.5 力月で, 手術単独群の 2.5 力月に比し有意に長く, 術後 照射は有用であったとしている．自験例のうち術後照 射を施行した 3 例は脳再発を認めなかったが, 照射し なかった 2 例は脳再発を認めた。浅扭ら”は, $30 \mathrm{~Gy}$ 以 上の全脳照射により $56^{\circ}$ 。の患者に脳萎縮が出現したと 報告してい\%。自験例では全脳照射を施行した 3 例に， 明らかな脳萎縮や痴呆化の出現を認めなかった。

Nakagawa $ら^{8)}$ は, 脳転移巣摘出術後 5 年以上の長 期生存18例を検討し, 単発例, 転移巣全摘出例, テン 卜上腫場が予後良好と述べている．Yardeni ら"抙 術および術後照射を施行した単発性転移性脳腫瘍73例 の平均生存期間は, テント上7.5力月, テント下 2 力月 であり，テント下は有意に予後不良であったと報告し ている．自験例の症例 5 はテント下腫瘍であったが手 術を含む集学的治療で原発栄手術後 1 年以上の生存を 得た。小脳転移の予後は不良であるが，短期間に死に 至るため，全身状態が許せば手術適応を考慮すべきと 考えている。

肺癌脳転移例の治療方針に関し, 松谷ら”住, 転移单 に対する積極的治療（手術および放射線療法）の適応 は肺切除可能例に限るとしている。一方 Torre ら は, 肺原発巣と同時性単発性脳転移巣をともに切除し た21例を検討し，原発巣の $\mathrm{N}$ 因子が $\mathrm{N} 002$ 年生存率 が65\%に対し，N1または N2では17\%， と不良であり， 原発巣のリンパ節転移の有無が予後に関与していると 述へている．自験例の肺癌 3 例においても，予後不良 の 2 例（症例 1，2）はともに pN2で，予後良好の 1 例（症例 3）はpNoであった。

食道癌脳転移例は一般に原発单が進行した症例が多 く予後不良とされているが，Koga ${ }^{111}$ は原発巣への 積極的な放射線療法の併用により 1 年生存率は $37.5 \%$ と他臓器原発に比し特に予後不良でなかったと報告し ている，自験例（症例 4）に扔いても手術を含む集学 的治療により, 術後 2 年 6 力月以上の生存が得られた。

乳癌脳転移例は，化学療法やホルモン療法に反応す
ることが多く ${ }^{12)}$ ，肺原発例に比し予後良好である ${ }^{(3)}$ とより，積極的治療の適応をより拡大して良いと考え られる。自験例（症例 5 ）は原発巣の進行度が高度で あったため長期生存は得られなかった。

以上より，脳先行型に対して，原発巣の進行度を考 虑したうえでの積極的な原発巣切除は予後の改善に有 用と考えられた。

\section{結語}

脳転移巣摘出術後に原発癌病巣切除を施行した 5 症 例の臨床的検討を行った，積極的な脳転移巣摘出，原 発紧切除および術後全脳照射は予後の改善に有用と考 えられた。

\section{文献}

1）小林清市, 古城信人, 宮城 潤他：転移性脳腫晹の 外科的治療成績について，脳神外科 $13: 825$ 830,1985

2）松谷雅生：脳転移の治療一肺嵒脳転移を中心とし て一。外科治療 $63: 150-154,1990$

3）徳力康彦，山下純考：半田 臂：転移性脳腫癔の診 断, 集学的治療, 問題点. 最新医 $41: 2365-2370$, 1986

4) Mandell L, Hilaris B, Sullivan M, et al: The treatment of single brain metastasis from nonoat cell lung carcinoma : Surgery and radiation versus radiation therapy alone. Cancer $58: 641$ $-649,1986$

5) Patchell RA, Tibbs PA, Walsh JW, et al: A randomized trial of surgery in the treatment of single metastases to the brain. N Engl J Med $322: 494-\cdot 500,1990$

6）山下純宏：脳転移の手術的療法. 癌の臨 30 : $1010-1016,1984$

7) 浅井昭雄, 松谷雅生, 高倉公朋：脳腫瘍放射治療後 の亜急性障害としての脳萎縮と痴呆. 癌の臨 $33:$ $753-761,1987$

8) Nakagawa H, Kimura S, Kubo S, et al: Prognostic factors in patients surviving for more than 1 or 5 years after removal of metastatic brain tumors. Neurol Med Chir (Tokyo) $32: 947$ $-951,1992$

9) Yardeni D, Reichenthal E, Zucker G, et al : Neurosurgical management of single brain metastasis. Surg Neurol 21:377-384, 1984

10) Torre M, Quaini E, Chiesa G, et al : Synchronous brain metastasis from lung cancer: 
Results of surgical treatment in combined resection. J Thorac Cardiovasc Surg 95: 994-997. 1988

11) Koga H, Mukawa J, Miyagi K, et al: Treatment of metastatic brain tumor from esophageal carcinoma -Report of four cases. Neurol Med Chir (Tokyo) 31:518-522, 1991

12) Boogerd W, Dalesio O, Bais EM, et al:
Response of brain metastases from breast can cer to systemic chemotherapy. Cancer $69: 972-$ 980,1992

13) White KT, Fleming TR, Laws ER: Single metastasis to the brain : Surgical treatment in 122 consecutive patients. Mayo Clin Proc 56: $424-428,1981$

\title{
FIVE CASES OF METASTATIC BRAIN TUMOR WITH SURGICAL TREATMENT OF BOTH METASTATIC AND PRIMARY LESIONS
}

\author{
Masaya NOMURA, Kazuyasu NAKAO, Masaaki NAKAHARA, Nobuo OGINO, \\ Nobuhiro FUJITA, Katsuaki MAEDA, Takeyoshi YUMIBA, \\ Takashi EMOTO, Kazushi KUROZUMI \\ and Hideaki IWANAGA* \\ Department of Surgery and Neurosurgery*, Osaka Police Hospital
}

We report five cases of metastatic brain tumor preceded by neurological symptoms. All patients received removal of the brain tumors prior to resection of the primary lesions. The primary site of cancer was the lung in 3 patients, and esophagus and breast in one each. The number of brain tumor was one in four patients and 3 in one. The duration from the removal of the brain tumors to the resection of the primary lesions ranged from 0.5 to 6 months. Two patients with lung cancer, who did not undergo postoperative whole brain radiation therapy, died of recurrence of brain tumors 14 months and 15 months after the resection of the primary lesions, respectively. On the other hand, no recurrence of the brain tumor was found in 3 patients with postoperative whole brain radiation. One patient with breast cancer died 14 months, and two patients with esophageal and lung cancer are alive 30 months and 37 months after the resection of the primary lesions, respectively. Curative resection for both brain metastasis and primary lesions was performed in 2 patients surviving for more than two years.

Resection of brain metastasis and primary lesions, and postoperative whole brain radiation therapy according to the progressive extent of the lesions would improve the prognosis. 